\title{
DIFFERENCE IN LENGTH OF RETURN OF FERTILITY AFTER CONTRACEPTION WITH 3-MONTH OF DEPO MEDROXY PROGESTERON ACETATE INJECTION AND HORMONAL IMPLANT IN BAUMATA PUBLIC HEALTH CENTER, KUPANG DISTRICT
}

\author{
Siti Nur Asyah Jamillah Ahmaad, Dina M.S Henukh
}

Study Program in Diploma-III, Universitas Citra Bangsa, Kupang

\begin{abstract}
ABSTRAK
Background: The length of fertility after stopping the use of DMPA injection takes an average of 4 to 10 months, while the FP implant takes 1 to 3 months. This study aimed to analyze the difference in duration of fertility return at 3-month injection contraceptive post acceptors (DMPA) and implant contraception at Baumata Health Center.

Subjects and Method: This was an analytic study with a cross sectional design. The study was conducted in Baumata Community Health Center, Kupang Regency from November to December 2019. A sample of 40 post-acceptors for injection and implant family planning was selected by sampling technique. The dependent variable was Length of return of fertility. The independent variables were post acceptors for injection and implant family planning. The data were collected by questionnaire and tested by Mann-Whitney test.

Results: Length of return to fertility in post-acceptors of injection family planning mothers at Baumata Public Health Center (Mean= 7.65; $\mathrm{SD}=2.23$ ). The return of fertility to post-acceptor implant family planning mothers at Baumata Community Health Center, Kupang Regency (Mean=3.05; $\mathrm{SD}=0.99)$. It was statistically significant $(\mathrm{p}<0.001)$.

Conclusion: Based on the tests that have been carried out, it can be concluded that there is a difference in the duration of return of fertility in mothers of injection and implant family planning post acceptors at Baumata Community Health Center, Kupang Regency.

Keywords: injection and implant family planning post acceptors, duration of return of fertility

\section{Correspondence:}

Siti Nur Asyah Jamillah Ahmad. Study Program in Diploma-III, Universitas Citra Bangsa, Kupang. Jl. Manafe No. 17 Kayu Putih, Oebobo district, East Nusa Tenggara, Indonesia. E-mail: sitinurahmad17@yahoo.com. Mobile: 085338191820
\end{abstract}

The $7^{\text {th }}$ International Conference on Public Health

Solo, Indonesia, November 18-19, 2020 | 216 https://doi.org/10.26911/the7thicph.03.36 